\title{
Brazilian Journal of Chemical

\section{PURIFICATION OF RECOMBINANT APROTININ PRODUCED IN TRANSGENIC CORN SEED: SEPARATION FROM CTI UTILIZING ION-EXCHANGE CHROMATOGRAPHY}

\author{
A. R. Azzoni ${ }^{1}$, K. Takahashi ${ }^{1}$, S. L. Woodard ${ }^{2,3}$, E. A. Miranda ${ }^{1 *}$ \\ and Z. L. Nikolov ${ }^{2,3}$ \\ ${ }^{1}$ LEBp: Laboratório de Engenharia de Bioprocessos, Departamento de Processos \\ Biotecnológicos, Phone: +(55) (19) 3788-3918, FEQ, UNICAMP, \\ CP 6066, CEP 13083-970, Campinas - SP, Brazil. \\ E-mail: everson@feq.unicamp.br \\ ${ }^{2}$ ProdiGene, College Station, TX 77845, USA \\ ${ }^{3}$ Biological and Agricultural Engineering, Texas A\&M University, \\ College Station, Texas 77843-2117, USA.
}

(Received: July 30, 2004 ; Accepted: February 23, 2005)

\begin{abstract}
Protein expression in transgenic plants is considered one of the most promising approaches for producing pharmaceutical proteins. As has happened with other recombinant protein production schemes, the downstream processing $(\mathrm{dsp})$ of these proteins produced in plants is key to the technical and economic success of large-scale applications. Since dsp of proteins produced transgenically in plants has not been extensively studied, it is necessary to broaden the investigation in this field in order to more precisely evaluate the commercial feasibility of this route of expression. In this work, we studied the substitution of an IMAC chromatographic step, described in previous work (Azzoni et al., 2002), with ion-exchange chromatography on SP Sepharose Fast Flow resin as the second step in the purification of recombinant aprotinin from transgenic maize seed. The main goal of this second purification step is to separate the recombinant aprotinin from the native corn trypsin inhibitor. Analysis of the adsorption isotherms determined at $25^{\circ} \mathrm{C}$ under different conditions allowed selection of $0.020 \mathrm{M}$ Tris $\mathrm{pH} 8.5$ as the adsorption buffer. The cation-exchange chromatographic process produced a high-purity aprotinin that was more than ten times more concentrated than that generated using an IMAC step.

Keywords: Recombinant aprotinin; Transgenic corn; Protease inhibitor purification; Downstream processing; Ion-exchange chromatography.
\end{abstract}

\section{INTRODUCTION}

Aprotinin, also known as bovine pancreatic trypsin inhibitor, is an inhibitor of serine proteases including kallikrein, trypsin, and chymotrypsin. First isolated from bovine sources by Kunitz and Northrop (1936), it is a single-chain polypeptide made up of 58 amino acid residues with a molecular mass of 6.5 $\mathrm{kDa}$. Aprotinin has applications as a protease inhibitor in tissue cultures and is also an expensive drug used during cardiac surgery (Beath et al., 2000). Bovine lung has been the commercial source of pharmaceutical-grade aprotinin. The bovine source of pharmaceutical proteins poses concerns about

*To whom correspondence should be addressed 
possible product contamination with bovine spongiform encephalopathy (BSE). Consequently, alternative systems of aprotinin production have been pursued. Recombinant aprotinin has been expressed in Escherichia coli (Auerswald et al., 1987), Pichia pastoris (Vedvick et al., 1991), Sacharomyces cerevisiae (Norris et al., 1990), and Hansenula polymorpha (Zurek et al., 1996).

Taking into account the important advantages of plants over other expression systems, such as low production and scale-up costs, the natural storage stability of the recombinant proteins in tubers or seeds, and the fact that transgenic plants do not propagate human or animal pathogens (Cramer et al., 2000; Hood and Howard, 1999; Kusnadi et al., 1997), the expression of aprotinin in maize seeds was studied by Zhong et al. (1999). Now, recombinant aprotinin produced in maize seeds is commercially available under the name of AproliZean $^{\mathrm{TM}}$ (Prodigene, 2004).

Recently, Azzoni et al. (2002) reported the extraction and purification of recombinant aprotinin produced in maize seeds utilizing a two-step chromatographic process. After aqueous extraction of transgenic seed flour, aprotinin was adsorbed from the liquid phase in an immobilized trypsin affinity column together with the native corn trypsin inhibitor CTI. Then, immobilized metal ion chromatography (IMAC) used in a negative mode, removed CTI from the recombinant aprotinin. Although the two-step process produced aprotinin of high purity and yield, this purification method had two disadvantages: possible contamination of the final product with metal ions that could be difficult and/or expensive to remove and excessive dilution of the recombinant aprotinin during the negative-mode IMAC step. Therefore, the objective of this work was to evaluate the possibility of substituting a cation-exchange chromatographic step for the IMAC step to separate CTI from aprotinin, since ion exchange does not have metal leakage and major dilution problems. The rationale for selecting a cation-exchange step includes the following considerations: 1) the significant difference in $\mathrm{pI}$ between aprotinin (10.5) and CTI isoforms (5.1-7.3) (Hojima et al., 1980), 2) the low cost of resin, and 3) ion-exchange scalability and robustness.

\section{MATERIALS AND METHODS}

\section{Materials}

The transgenic corn seed containing the recombinant aprotinin used in this work was the same as that used by Zhong et al. (1999). The HiTrap column loaded with SP Sepharose Fast Flow resin (cation-exchange resin) was purchased from Amersham-Pharmacia, USA. N- $\alpha$-benzoyl-DLarginine-p-nitroanilide (BApNA), bovine trypsin (Type I), and aprotinin were purchased from Sigma, USA. CTI was purified from nontransgenic corn seed according to Swartz et al. (1977). The Coomassie Plus Protein Reagent was from Pierce, USA. All other chemicals used in this work were of at least reagent grade.

\section{Methods}

\section{- Transgenic Corn Seed Grinding}

Seeds were ground to a particle size smaller than $0.85 \mathrm{~mm}$ using an Intermediate Model laboratoryscale mill from Thomas-Wiley, USA.

\section{- Analytical Assays}

Total protein concentration was determined by using the Pierce Coomassie Plus Protein Assay (Pierce, USA). Trypsin inhibition assay was carried out according to the Sigma Enzymatic Assay of Aprotinin per Kassel (1970). One trypsin unit was defined as the amount of enzyme that hydrolyzes 1.0 $\mu \mathrm{mol}$ of BApNA per minute at $\mathrm{pH} 7.8$ and $25^{\circ} \mathrm{C}$. One trypsin inhibition unit was defined as the amount of inhibitor that decreases the activity of two trypsin units by $50 \%$. Aprotinin was quantified by ELISA according to Zhong et al. (1999). All assays were done in triplicate, and the final aprotinin concentration of each sample was expressed as the mean of the three replicates. Electrophoresis was carried out under denaturing conditions (SDS-PAGE) as described by Zhong et al. (1999).

\section{- Determination of Adsorption Isotherms}

The adsorption isotherms of aprotinin and CTI on the cation-exchange resin (SP Sepharose Fast Flow) were generated at $25^{\circ} \mathrm{C}$ using $1.5 \mathrm{~mL}$ Eppendorf tubes. Six different adsorption buffers were used: $0.020 \mathrm{M}$ Tris and $0.030 \mathrm{M}$ sodium phosphate buffers at $\mathrm{pH}$ values of 7.5 and 8.5 and $0.020 \mathrm{M}$ Tris $\mathrm{pH} 8.5$ containing 0.100 and $0.200 \mathrm{M} \mathrm{NaCl}$, respectively. Five milligrams of drained resin previously equilibrated with a specific adsorption buffer was added to $1.0 \mathrm{~mL}$ of the desired protein solution prepared in the same buffer. The adsorption isotherm 
experiments were conducted as described by Azzoni and Miranda (1999). A nonlinear regression fit of the experimental data was done using the Langmuir adsorption model (Langmuir, 1916).

\section{- Aprotinin Extraction and Affinity Chromatography on Trypsin-Agarose Resin}

Aqueous extraction of the recombinant aprotinin and its recovery utilizing affinity chromatography on immobilized trypsin was carried out according to Azzoni et al. (2002). Typically, two hundred grams of aprotinin corn meal were mixed with $1.0 \mathrm{~L}$ of water for $30 \mathrm{~min}$ at $\mathrm{pH} 3.0(\mathrm{pH}$ controlled by addition of $1.0 \mathrm{M} \mathrm{HCl}$ ). Filtered liquid phase was adjusted to pH 7.8 using a $1.0 \mathrm{M} \mathrm{NaOH}$ solution. The affinity chromatography was carried out with a $16 \times 100 \mathrm{~mm}$ XK16 column (Pharmacia, Sweden) with $10 \mathrm{~mL}$ of trypsin-agarose resin. The column was equilibrated using $50 \mathrm{mM} \mathrm{NaPi}$ buffer $\mathrm{pH} 7.8$ with $0.25 \mathrm{M}$ $\mathrm{NaCl}$. After loading the sample $(775 \mathrm{~mL}$ at 2.0 $\mathrm{mL} / \mathrm{min}$ ), the column was washed with $50 \mathrm{mM}$ $\mathrm{NaPi}$ buffer pH 7.8 containing $0.6 \mathrm{M} \mathrm{NaCl}$. The elution step was done with $50 \mathrm{mM} \mathrm{KCl}-\mathrm{HCl} \mathrm{pH}$ 2.0 and $3.0 \mathrm{~mL} / \mathrm{min}$. The eluted fractions $(4.0 \mathrm{~mL})$ were immediately diluted $1: 1$ with $0.04 \mathrm{M}$ Tris buffer $\mathrm{pH} 8.5$ (final Tris concentration of 0.020 $\mathrm{M})$, combined, and then adjusted to $\mathrm{pH} 8.5$ with 1.0 $\mathrm{M} \mathrm{NaOH}$.

\section{- Ion-Exchange Chromatography}

Ion-exchange chromatography was carried out using SP Sepharose Fast Flow packed in a $1.0 \mathrm{~mL}$ HiTrap column. The column was equilibrated with $0.020 \mathrm{M}$ Tris $\mathrm{pH} 8.5$ (buffer A). The eluted peak from the affinity chromatography containing the high aprotinin concentrations were combined as a pool and fed into the SP-Sepharose column (only the first two fractions of this peak with a high protein concentration - mainly corn trypsin inhibitor - but a low aprotinin concentration were discarded, as previously described by Azzoni et al. (2002)). The column was then washed with $5 \mathrm{~mL}$ of buffer A. Elution was accomplished with a linear gradient of 0 to $1.5 \mathrm{M} \mathrm{NaCl}$ in buffer A using 20 column volumes $(20 \mathrm{~mL})$. All chromatographic steps were performed at a flow rate of $1.0 \mathrm{~mL} / \mathrm{min}$. The flow-throughs of the feeding and washing steps were collected as two separate pools and analyzed for aprotinin, total soluble protein, and trypsin inhibition along with the $1.5 \mathrm{~mL}$ fractions from the elution step.

\section{RESULTS AND DISCUSSION}

\section{Determination of Adsorption Isotherms}

The goal of the adsorption isotherm experiments was to identify conditions that allowed for maximum binding of aprotinin while minimizing the amount of CTI binding to the cation-exchange resin. Conditions examined included type of ion, $\mathrm{pH}$, and the effect of $\mathrm{NaCl}$ in the adsorption buffer. Kinetic experiments were first carried out to determine the time needed to guarantee that equilibrium was achieved in the adsorption of aprotinin. This experiment was conducted using a $0.020 \mathrm{M}$ Tris $\mathrm{pH} 7.5$ buffer at $25^{\circ} \mathrm{C}$. Since aprotinin liquid phase concentration stabilized after an adsorption time of just over $1 \mathrm{~h}$ (Figure 1), the adsorption time for isotherm experiments was set to $2 \mathrm{~h}$.

Next, the effect of Tris and phosphate buffer ions on the adsorption of aprotinin and CTI was compared. Figure 2 shows the adsorption isotherms obtained at $25^{\circ} \mathrm{C}$ for aprotinin and CTI binding to the cationexchange resin with the Tris buffer at either $\mathrm{pH} 7.5$ or $\mathrm{pH}$ 8.5. Figure 3 shows the results of the same experiment performed in phosphate buffer. The shape of aprotinin isotherms is of the Langmuirian type, indicating specific interaction of aprotinin in both buffers and pHs. CTI isotherms were linear in both buffers and suggest nonspecific, weak interactions with the resin. The significant difference in adsorption at equilibrium between aprotinin and CTI under all conditions studied (Figures 2 and 3) indicates the possibility of cationexchange chromatographic separation of aprotinin and CTI. The equilibrium binding parameters of aprotinin, calculated by a nonlinear regression fit of the experimental data in Figures 2 and 3, are shown in Table 1. Adsorption capacities for aprotinin were at least five to eighteen times higher than those for CTI. The lower adsorption $\mathrm{pH}$ allowed a higher adsorption capacity for aprotinin $\left(\mathrm{q}_{\mathrm{m}}\right)$ and stronger interaction between aprotinin and the resin adsorption sites (indicated by a lower $\mathrm{K}_{\mathrm{d}}$ ). Because the greatest difference in adsorption between the two proteins was measured in Tris $\mathrm{pH} 8.5$, all subsequent experiments were performed in this buffer.

The effect of salt (ionic strength) on adsorption of aprotinin was also checked at two different $\mathrm{NaCl}$ concentrations. The data presented for adsorption of aprotinin in $0.020 \mathrm{M}$ Tris $\mathrm{pH} 8.5$ were plotted together with data for adsorption in this same buffer with 0.1 or $0.2 \mathrm{M} \mathrm{NaCl}$ (Figure 4). The results indicated that $\mathrm{NaCl}$ drastically reduces the adsorption of aprotinin onto the resin and aprotinin could be desorbed in a step change using a $\mathrm{NaCl}$ concentration higher than $0.2 \mathrm{M}$. 


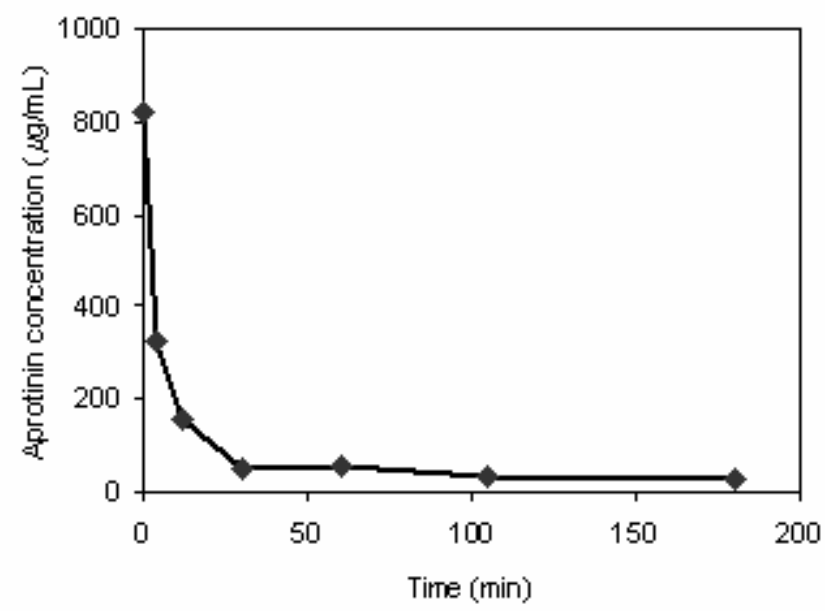

Figure 1: Kinetics of aprotinin adsorption onto SP Sepharose Fast Flow ion-exchange resin. Adsorption buffer, $0.020 \mathrm{M}$ Tris $\mathrm{pH} 7.5$; temperature, $25^{\circ} \mathrm{C}$; initial aprotinin concentration, $0.82 \mathrm{mg} / \mathrm{mL}$.

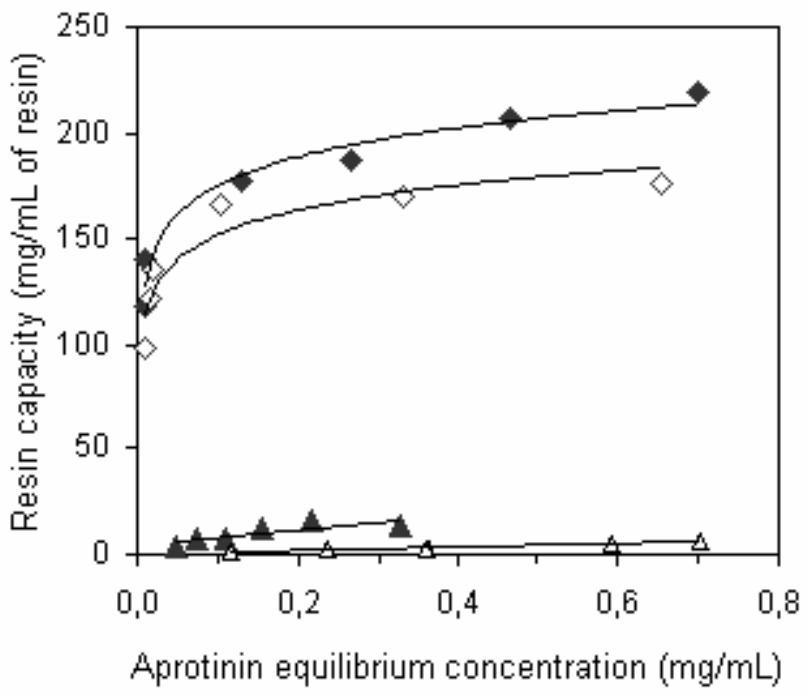

Figure 2: Adsorption isotherm of aprotinin $(\bullet)$ and CTI $(\boldsymbol{\Delta})$ on SP Sepharose Fast Flow ion-exchange resin at $25^{\circ} \mathrm{C}$ in $0.020 \mathrm{M}$ Tris $\mathrm{pH} 7.5$ (full symbols) and 8.5 (empty symbols).

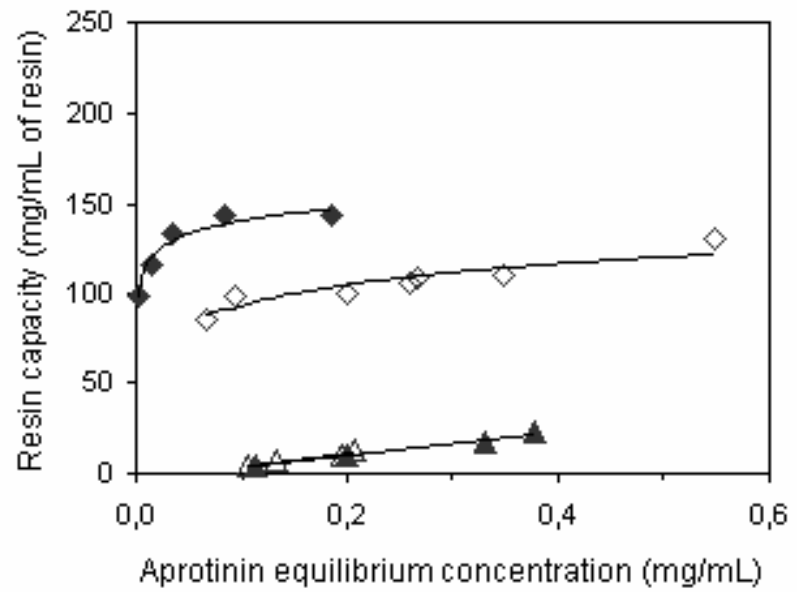

Figure 3: Adsorption isotherm of aprotinin $(\bullet)$ and CTI (४) on SP Sepharose Fast Flow ion-exchange resin at $25^{\circ} \mathrm{C}$ in $0.030 \mathrm{M}$ sodium phosphate buffer $\mathrm{pH} 7.5$ (full symbols) and 8.5 (empty symbols). 
Table 1: Equilibrium parameters for aprotinin adsorption onto SP Sepharose Fast Flow resin with Tris and NaPi buffers.

\begin{tabular}{|l|c|c|c|c|}
\hline $\begin{array}{l}\text { Equilibrium } \\
\text { parameter }\end{array}$ & Tris pH 7.5 & Tris pH 8.5 & NaPi pH 7.5 & NaPi pH 8.5 \\
\hline $\mathbf{q}_{\mathbf{m}}(\mathbf{m g} / \mathbf{m L})$ & 215 & 177 & 145 & 135 \\
$\mathbf{K}_{\mathbf{d}}(\mathbf{m g} / \mathbf{m L})$ & $1.2 * 10^{-2}$ & $7.2 * 10^{-2}$ & $0.22 * 10^{-2}$ & $5.6 * 10^{-2}$ \\
\hline
\end{tabular}

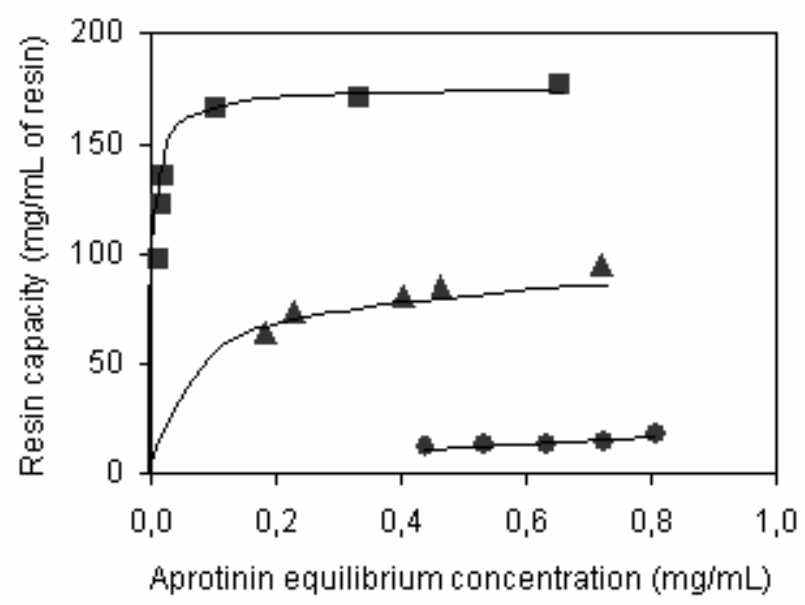

Figure 4: Adsorption isotherm of aprotinin onto SP Sepharose Fast Flow in $0.020 \mathrm{M}$ Tris pH 8.5 with zero $(\bullet), 0.1 \mathrm{M}(\boldsymbol{\bullet})$, and $0.2 \mathrm{M}(\bullet) \mathrm{NaCl}$. Temperature, $25^{\circ} \mathrm{C}$.

\section{Recombinant Aprotinin Purification Using Cation- Exchange Chromatography}

Having determined the condition of high adsorption of aprotinin onto the SP Sepharose Fast Flow resin, a pool of fractions eluted from a trypsinagarose chromatographic column containing aprotinin was chromatographed on this cation-exchange resin. The fractions were analyzed for protein and aprotinin contents and trypsin activity inhibition. The profiles obtained are presented in Figure 5. Mass and activity balances for the whole process (extraction, affinity, and ion-exchange chromatographies) are presented in Table 2.

Just one protein peak containing aprotinin was detected. Despite the error in the ELISA method that overestimated the amount of aprotinin eluted (equivalent to $125 \%$ of the aprotinin fed into the ionexchange column), we can interpret that this polypeptide was successfully adsorbed and eluted from the column. The ion-exchange chromatographic step and overall purification factors (9.5 and 465, respectively) were higher than those reported by Azzoni et al. (2002) (4.5 and 280, respectively). The overall yield found $(37 \%)$ was lower than that previously described (49\%), mainly due to a column overload during the affinity chromatographic step. SDS-PAGE of the samples of the ion-exchange chromatography confirmed the high level of purification of the recombinant aprotinin (Figure 6). The pool of fractions in which the purified recombinant aprotinin was expected to elute showed just one band in SDS-PAGE (lane 5), indicating the high purity of this preparation. The pool of eluted fractions from the affinity column (feed for the ionexchange column, lane 3) contains three bands. The band with intermediate molecular mass is composed in part of aprotinin and is found there at low concentration. This can be realized by analyzing the flow-through of the ion-exchange column. It contains just 3\% of the aprotinin fed onto the resin (lane 2) and the rest is CTI. Under reducing conditions for SDS-PAGE, the two-chain CTI (14 kDa) can be seen on the gel as two polypeptides of approximately 8.0 and $5.0 \mathrm{kDa}$ each resulting from the cleavage of the molecule by the immobilized trypsin in the affinity column (Lei and Reeck, 1986). The flow through fraction (lane 4) contained the CTI. For comparison, aprotinin purified by the method described by Azzoni et al. (2002) was loaded in lane 6. 

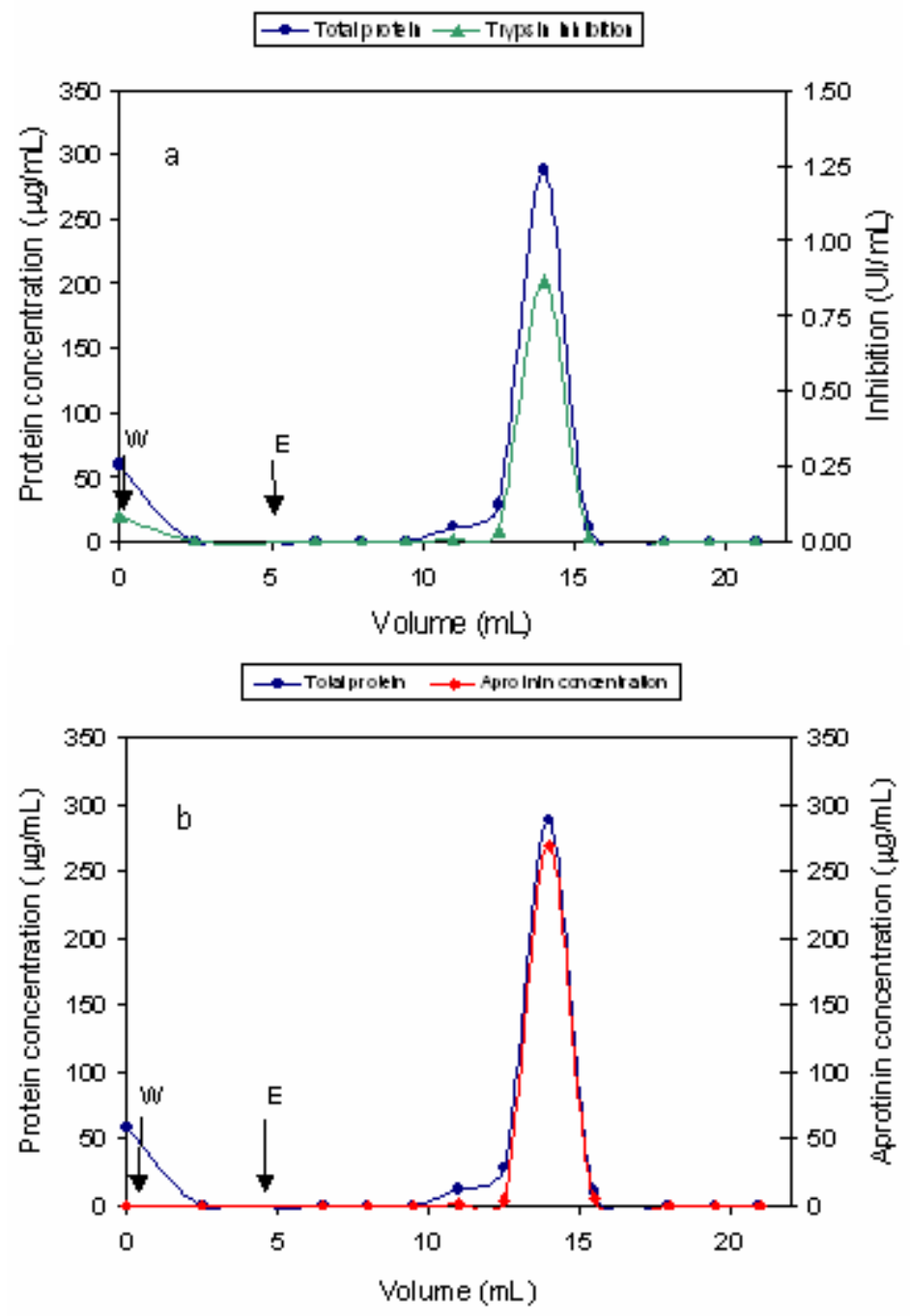

Figure 5: SP Sepharose Fast Flow ion-exchange chromatographic profiles for the separation of recombinant aprotinin from CTI. Feed: eluted fractions from the tryspin-agarose chromatography of transgenic corn seed aqueous extract. a) Total protein and inhibition profiles; b) Total protein and aprotinin concentration profiles. A sample of $52 \mathrm{~mL}$ of extract was loaded into the column and washed with $0.020 \mathrm{M}$ Tris buffer $\mathrm{pH}$ 8.5. The bound proteins were eluted with a $\mathrm{NaCl}$ linear gradient in this same buffer. Aprotinin was eluted from the column at a concentration of approximately $0.4 \mathrm{M} \mathrm{NaCl}$. W and $\mathrm{E}$ indicate the beginning of the washing and elution steps, respectively.

Table 2: Purification of recombinant aprotinin (rAprotinin) from transgenic corn seed extract*.

\begin{tabular}{|l|c|c|c|c|c|c|}
\hline Step & $\begin{array}{c}\text { Volume } \\
(\mathbf{m L})\end{array}$ & $\begin{array}{c}\text { Protein } \\
(\mathbf{m g})\end{array}$ & $\begin{array}{c}\text { Inhibition } \\
(\mathbf{I U})\end{array}$ & $\begin{array}{c}\text { rAprotinin } \\
(\mathbf{m g})\end{array}$ & $\begin{array}{c}\text { rAprotinin } \\
\text { yield (\%) }\end{array}$ & $\begin{array}{c}\text { Purification } \\
\text { factor }\end{array}$ \\
\hline $\begin{array}{l}\text { Extraction } \\
\text { Affinity }\end{array}$ & 1500 & 632 & 27 & 1.12 & 100 & 1 \\
$\begin{array}{l}\text { Eluate } \\
\text { SP-Sepharose }\end{array}$ & 39 & 7.7 & 15 & 0.44 & $40 * *$ & 32 \\
Load & $52 * * *$ & 3.9 & 6.5 & 0.34 & 30 & 49 \\
Flow through & 52 & 0.39 & 4.4 & 0.01 & 1 & - \\
Eluate & 6 & 0.5 & 1.4 & 0.42 & 37 & 465 \\
\hline
\end{tabular}

*Extraction and affinity chromatography carried out according to Azzoni et al. (2002).

** Low yield due to column overload during affinity step.

***Eluted fractions from the affinity chromatography containing high aprotinin concentrations were combined and diluted $1: 1$ with $0.04 \mathrm{M}$ Tris buffer $\mathrm{pH} 8.5$ before column loading. The first two fractions from the affinity column elution peak having a high protein concentration (mainly CTI) but a low aprotinin concentration were discarded, as previously described by Azzoni et al. (2002). 


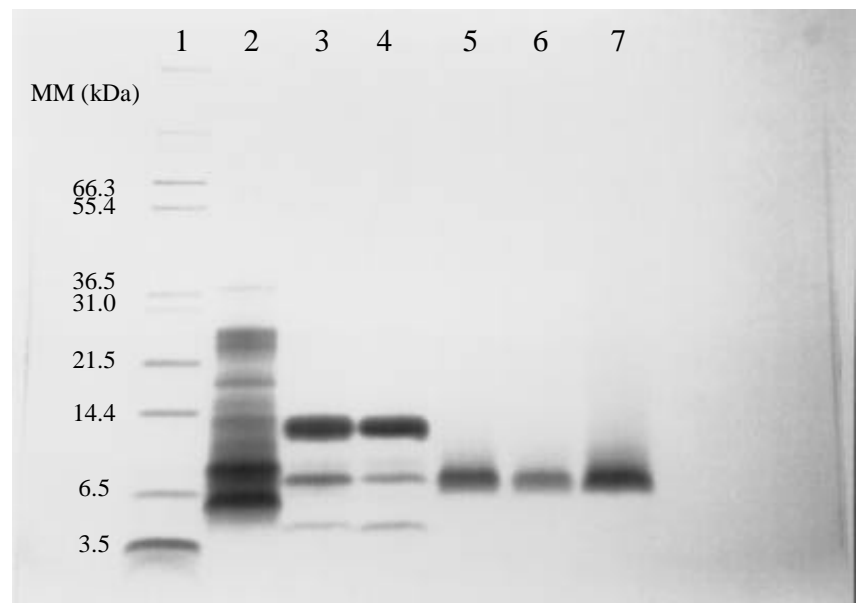

Lane 1 - Molecular mass markers;

Lane 2 - Extracted corn proteins loaded into the affinity column (20 $\mu \mathrm{g}$ of protein);

Lane 3 - Proteins eluted from the affinity column and loaded into the ion exchange column (10 $\mu \mathrm{g}$ of protein); Lane 4 - Flow-through from the ion-exchange column (10 $\mu \mathrm{g}$ of protein);

Lane 5 - Protein eluted from the ion-exchange column (recombinant aprotinin) (3.0 $\mu \mathrm{g}$ of protein);

Lane 6 - Recombinant aprotinin purified according to Azzoni et al. (2002) (3.5 $\mu \mathrm{g}$ of protein);

Lane 7 - Commercial aprotinin $(6.5 \mu \mathrm{g}$ of protein). Acrylamide gel (10 to $20 \%$ gradient) in Tris/Tricine buffer.

Figure 6: SDS-PAGE of the samples from a recombinant aprotinin recovery and purification process having SP Sepharose Fast Flow as the second purification step. The first chromatographic step on trypsin-agarose resin was as described by Azzoni et al. (2002).

\section{CONCLUSIONS}

In this work adsorption isotherms were obtained for the binding of aprotinin and CTI to a cationexchange resin and binding parameters were determined for the different conditions examined. We further demonstrated that substitution of a cation-exchange chromatographic step for the IMAC chromatographic step of the purification process developed by Azzoni et al. (2002) is feasible. This ion-exchange purification step developed here had a significantly high recovery and a purification factor 2.1 times higher than that of the IMAC step. More striking was the concentration of purified aprotinin: the ionexchange chromatography produced a recombinant aprotinin solution over ten times more concentrated than the IMAC product.

\section{ACKNOWLEDGMENTS}

Authors (A.R. Azzoni and E.A. Miranda) gratefully acknowledge the financial support of the Coordenação de Aperfeiçoamento de Pessoal de Ensino Superior (CAPES), Brazil and the Fundação de Amparo a Pesquisa do Estado de São Paulo (FAPESP), Brazil. A. Azzoni thanks Iowa State University for sponsoring his research program in the United States. We also thank Dra. Sonia Maria Alves Bueno (Universidade Estadual de Campinas, Brazil) for the fruitful discussions and assistance during this work.

\section{REFERENCES}

Auerswald, E.A., Schröder, W. and Kotick, M., Synthesis, cloning and expression of recombinant aprotinin, Biol. Chem. Hoppe-Seyler, 368, 14131425 (1987).

Azzoni, A.R., Kusnadi, A.R., Miranda, E.A. and Nikolov, Z.L., Recombinant aprotinin produced in transgenic corn seed: extraction and purification studies, Biotechnol. Bioeng., 80, 268-276 (2002).

Azzoni, A.R. and Miranda, E.A., Recovery of aprotinin from insulin industrial process effluent by affinity adsorption, Bioproc. Eng., 21, 553560, (1999).

Beath, S.M., Nuttall, G.A., Fass, D.N., Oliver Jr, W.C., Ereth, M.H. and Oyen, L.J., Plasma aprotinin concentrations during cardiac surgery: full-dose versus half-dose regimens, Anesth. Analg., 91, 257-264 (2000).

Cramer, C.L., Boothe, J.G. and Oishi, K.K., Transgenic plants for therapeutic proteins: linking upstream and downstream strategies. In "Plant biotechnology: new products and applications", Hammond, J., McGarvey, P. and Yusibov, V., Eds., New York, Springer, pp. 95-115 (2000).

Hojima, Y., Pierce, J.V. and Pisano, J.J., Hageman factor fragment inhibitor in corn seeds: purification and characterization, Thromb. Research, 20, 149-162 (1980).

Hood, E.E. and Howard, J.A., Protein products from transgenic plants, Agro-Food-Industry Hi-Tech., May/June, pp 35-36 (1999). 
Kassel, B., Bovine trypsin-kallikrein inhibitor (Kunitz inhibitor, basic pancreatic trypsin inhibitor, polyvalent inhibitor from bovine organs), Meth. Enzymol., 19, 844-852 (1970).

Kunitz, M. and Northrop, J.H., Isolation from beef pancreas of crystalline trypsinogen, trypsin inhibitor, and an inhibitor trypsin compound, J. Gen. Physiol., 19, 991-1007 (1936).

Kusnadi, A.R., Nikolov, Z.L. and Howard, J.A., Production of recombinant proteins in transgenic plants: practical considerations, Biotechnol. Bioeng., 56, 473-484 (1997).

Langmuir, I., The constitution and fundamental properties of solids and liquids, J. Amer. Chem. Soc., 38, 2263-2295 (1916).

Lei, M.G. and Reeck, G.R., Combined use of trypsinagarose affinity chromatography and reversedphase high-performance liquid chromatography for the purification of single-chain protease inhibitor from corn seeds, J. Chromat., 363, 315321 (1986).

Norris, K., Norris, F., Bjorn, S.E., Diers, I. and Petersen, C., Aprotinin and aprotinin analogues expressed in yeast, Biol. Chem. Hoppe-Seyler, 371, 37-42 (1990).

Prodigene. Internet site www.prodigene.com/pdf/AproliZean (tm)\%20Backgrounder.pdf, on April 9, 2004.

Swartz, M.J., Mitchell, H.L., Cox, D.J. and Reeck, G.R., Isolation and characterization of trypsin inhibitor from opaque-2 corn seeds, J. Biol. Chem., 252, No. 22, 8105-8107 (1977).

Vedvick, T., Buckholz, R.G., Engel, M., Urcan, A., Kinney, J., Provow, S., Siegel, R.S. and Thill, G.P., High level secretion of biologically active aprotinin from yeast Pichia pastoris, J. Ind. Microb., 7, 197-202 (1991).

Zhong, G.Y., Peterson, D., Delaney, D.E., Bailey, M., Wicher, D.R., Register, J.C., Bond, D., Li, C.P., Marshall, L., Kulisek, E., Ritland, D., Meyer, T., Hood, E.E. and Howard, J.A., Commercial production of aprotinin in transgenic maize seeds, Mol. Breed., 5, 345-356 (1999).

Zurek, C., Kubis, E., Keup, P., Hörlein, D., Beunink, J., Thömmes, J., Kula, M.R., Hollemberg, C.P. and Gellissen, G., Production of two aprotinin variants in Hansenula polymorpha, Proc. Biochem., 7, 679-689 (1996). 